\title{
ERRATUM
}

Open Access

\section{Erratum To: On Stream Selection for Interference Alignment in Heterogeneous Networks}

\author{
Esra Aycan Beyazit ${ }^{1 *}$, Berna Özbek ${ }^{1}$ and Didier Le Ruyet ${ }^{2}$
}

After publication of our work [1] we noticed the following modifications.

- Eq. (3) should be written as follows.

$$
\hat{y}_{k}=D_{k}^{H} y_{k}
$$

- The dimension of $D_{k}$ given in the paragraph just before Eq. (3) should be corrected as $\mathrm{N}_{\mathrm{Rk}} \times \mathrm{q}_{\mathrm{k}}$.

Author details

${ }^{1}$ Electrical and Electronics Engineering Department, Izmir Institute of Technology, Urla, Izmir, Turkey. ${ }^{2}$ Conservatoire National Des Arts Et Métiers, Research lab CEDRIC/LAETITIA, Paris, France.

Received: 24 March 2016 Accepted: 24 March 2016

Published online: 24 March 2016

\section{References}

1. EA Beyazit, B Özbek, D Le Ruyet, On stream selection for interference alignment in heterogeneous networks. EURASIP J Wirel Commun Netw 2016(1), 1-18 (2016). doi:10.1186/s13638-016-0575-7

\footnotetext{
* Correspondence: esraaycan@iyte.edu.tr

${ }^{1}$ Electrical and Electronics Engineering Department, Izmir Institute of Technology, Urla, Ízmir, Turkey

Full list of author information is available at the end of the article
}

Submit your manuscript to a SpringerOpen ${ }^{\odot}$ journal and benefit from:

- Convenient online submission

- Rigorous peer review

- Immediate publication on acceptance

- Open access: articles freely available online

High visibility within the field

Retaining the copyright to your article

Submit your next manuscript at $>$ springeropen.com 